\title{
Challenging climate change and migration discourse: different understandings of time-scale and temporality in the Maldives
}

Article

Accepted Version

Arnall, A. and Kothari, U. (2015) Challenging climate change and migration discourse: different understandings of timescale and temporality in the Maldives. Global Environmental Change, 31. pp. 199-206. ISSN 0959-3780 doi:

https://doi.org/10.1016/j.gloenvcha.2015.01.011 Available at https://centaur.reading.ac.uk/39096/

It is advisable to refer to the publisher's version if you intend to cite from the work. See Guidance on citing.

Published version at: http://www.sciencedirect.com/science/article/pii/S0959378015000138

To link to this article DOI: http://dx.doi.org/10.1016/j.gloenvcha.2015.01.011

Publisher: Elsevier

All outputs in CentAUR are protected by Intellectual Property Rights law, including copyright law. Copyright and IPR is retained by the creators or other copyright holders. Terms and conditions for use of this material are defined in the End User Agreement.

www.reading.ac.uk/centaur 
Central Archive at the University of Reading

Reading's research outputs online 


\section{Challenging Climate Change and Migration Discourse: Different Understandings of Time-Scale and Temporality in the Maldives}

\section{Abstract}

This article draws on ongoing research in the Maldives to explore differences between elite and nonelite perceptions of climate change and migration. It argues that, in addition to variations in perceptions based on diverse knowledge, priorities and agendas, there exists a more fundamental divergence based upon different understandings of the time-scale of climate change and related ideas of urgency and crisis. Specifically, elites tend to focus on a distant future, which is generally abstracted from people's everyday lived realities, and to utilise the language of a climate change-induced migration 'crisis' in their discussions about impacts in a manner not envisaged by non-elites. The article concludes that, rather than unproblematically mapping global, external facing narratives wholesale onto ordinary people's lives and experiences, there needs to be more dialogue between elites and nonelites on climate change and migration issues. These perspectives should be integrated more effectively in the development of policy interventions designed to support people in adapting to the impacts of global environmental change.

\section{$1 \quad$ Re-thinking Climate Change and Migration}

It has long been recognised that changes in the environment can influence patterns and behaviours of human movement (El-Hinnawi, 1985). More recently, the impacts of climate change on population distribution and mobility are attracting growing interest with suggestions that climate change impacts will induce and increase population movements as migration becomes a significant potential adaptation strategy or a consequence of a failure to adapt (Tacoli, 2009). Recent empirical investigations into the relationship between climate change and migration have led to cautions about assuming a clearly delineated and inevitable link (Stojanov et al., 2014). In this context, more nuanced analyses of 
migration have emerged providing detailed empirical studies of the specific characteristics of migrant flows such as duration, destination and composition (Foresight: Migration and Global Environmental Change, 2011). Significantly, these highlight the importance of seeing migration as only one of an array of potential responses to environmental change, and as being inextricably linked to other socioeconomic and cultural dynamics.

While these studies have provided considerable insight into the relationship between climate change and migration, they have tended to rely on the perspectives of 'elites', such as climate change professionals and experts, while perceptions 'from below', or from non-elites, are largely absent or marginalised. In an attempt to address these shortcomings, recent studies have recognised the agency of vulnerable populations (Farbotko and Lazrus, 2011; Kelman, 2010; McNamara and Gibson, 2009), and identified social differences and inequalities amongst those affected (Marino and Ribot, 2012). This article builds on this work by examining the perceptions, experiences and responses of those perceived to be most immediately and directly affected by climate change. We suggest that, whilst there is increasing awareness of the differences between elites and non-elites in terms of understandings of how the climate is changing, the meanings attached to this, and the extent and form of response, such differences are not only based on diverse knowledge, priorities and agendas. Importantly, we propose that elite and non-elite accounts reveal a more fundamental divergence of perceptions, one that is based upon different understandings of the time-scale of climate change and related ideas of urgency and crisis. Specifically, elites tend to focus on a distant future which is generally abstracted from people's everyday lived realities, and take a long term perspective that can obscure more mundane concerns that may be more central to the present-day lives of non-elites. Moreover, experts often utilise the narrative of a climate-related 'crisis' in their discussions about future impacts, particularly those relating to future population displacements and migrations, whereas nonexperts do not envisage such changes with the same sense of urgency or inevitability. Thus, privileging 
elite perceptions may lead to the development of climate change policies that are inappropriate and unsustainable or, through their dominance, invisibilise more immediate livelihood priorities.

These issues are particularly relevant to small, low-lying island communities, which are considered to be amongst the most vulnerable to global economic and environmental change (CDKN, 2014) and, thus, have become prominent in debates on climate change and migration (Gerrard and Wannier, 2013). Sea-level rise and island inundation are commonly assumed to be the main cause of projected forced migration although empirical evidence for island disappearance under sea-level rise is limited (Ballu et al., 2012 ; Rankey, 2011 ; Webb and P.S, 2010 ). Other factors, such as reduced freshwater availability and the deaths of corals, might precede sea-level rise in forcing major changes to island life (Yamamoto and Esteban, 2014). This article draws on ongoing research in one such island group, the Maldives, in the Indian Ocean. Elite perceptions of climate change, and of migration as an adaptation strategy, were gathered from interviews with government personnel, nongovernmental organisations (NGOs), grassroots organisations and international agencies in 2013 and 2014. Additionally, non-elite knowledge of climate change and migration, and how changes to the climate are being observed, interpreted and felt, was explored through discussions with people living on central and peripheral islands in the same years.

The section that follows provides a discussion of how particular perspectives have been privileged in climate change discourse. It shows how the discourse has become increasingly professionalised, technicalised and overly-scientific resulting in the marginalisation of the perspectives of those most immediately affected by changes in the climate. The article then goes on to describe the case study context and methods in more detail, before exploring how understandings of time and temporality are currently shaping perceptions of climate change and migration. 


\section{$2 \quad$ Diverse actors and different perspectives}

Climate change exists as both a material phenomenon and a narrative (Farbotko and Lazrus, 2011). In recent years, a range of studies have examined narratives of climate change in developing country contexts in relation to issues such as involuntary resettlement (Arnall, 2014; Kothari, 2014) and disaster risk management (Gaillard, 2010; Mercer, 2010). Although diverse in their approaches, these studies are united by a common concern with whose voices are being expressed and acted upon as climate change policy is developed and implemented, and what the effects of these interventions are.

One framework with which to understand these dynamics is that of the discourse coalition. This is defined as a group of actors that share the usage of a particular set of storylines over a particular period of time (Hajer and Versteeg, 2005 ). By their very nature, discourse coalitions can provide powerful impetus for change or advancement of a particular issue or agenda. However, they can also reinforce 'exclusivity of knowledge' by defining environment and development-related problems as parts of complex systems that can only be understood by experts (Fischer and Hajer, 1999). These often discount the views and ideas of non-experts, portraying them as having the 'same interests, rationality, and aspirations' with little mention of their 'contradictory or conflicting needs, desires and interest' (Felli and Castree, 2012;2). The resulting outcome is a narrowing of the boundaries of what is viewed as legitimate social action, thus limiting space for political debate and dissent (Few et al., 2007; Skoglund and Jensen, 2013).

The discourse coalition that has developed around the climate change issue is largely based on the authority of science, and the increasingly technicalised and professionalised nature of the policy community that surrounds it (Arnall et al., 2014). One of the strongest voices in this community is that of the Intergovernmental Panel on Climate Change (IPCC), which presents its reports as the 'consensus view of the leading climate change experts in the world' (Hulme, 2007;8). The scientific and 
technical discourses of the IPCC are reproduced by international agencies and national governments when formulating interventions to promote action on climate change adaptation and mitigation (Lohmann, 2011). However, in drawing upon the authority of science in this manner, Hajer and Versteeg (2005) state that such actors will often, intentionally or unintentionally, present their arguments about environment and development as objective, factual and urgent, and thus beyond dispute. In this way, climate change has become one of the defining contemporary international development issues (Tanner and Allouche, 2011).

In spite of the dominance of the international climate change discourse coalition over the past 30 years, there is increasing awareness of the need to understand how the discourse becomes locally appropriated (Rudiak-Gould, 2014), and to integrate the perspectives, values and knowledge of 'ordinary' people or 'non-elites' who live in climate change affected places. For example, in relation to Small Island Developing States (SIDS), Paton and Fairbairn-Dunlop (2010) highlight the significance of local knowledge and beliefs to climate change and migration debates in Tuvalu, and Rudiak-Gould (2012) emphasises the difficulties associated with translating internationally-derived climate change terms into local languages and dialects in the Marshall Islands. These studies demonstrate that nonelite perspectives can bring to the fore different narratives, meanings and responses to climate change that are largely invisible in prevailing discourses, and also have the potential to uncover unequal social and environmental relations (Featherstone, 2013). This is important as such groups could provide new meanings, insights and solutions into the climate change and migration debate (Artur and Hilhorst, 2011). Climate change-related policies and interventions that overlook these alternative perspectives have the potential to prove unpopular (Patt and Schroter, 2008), exacerbate inequalities (Liverman, 2009) and place additional stress on already vulnerable communities (Marino and Ribot, 2012). 
In studying differences between elite and non-elite perceptions in the Maldives, we suggest that scientists tend to project longer-term future scenarios which contrast with the shorter-term, day-to-day and intergenerational lens of non-elites. This insight builds on recent scholarship exploring the temporal dimensions of vulnerability (Nielsen and Reenberg, 2010). One emerging theme from this strand of research is the contrast between the external temporal reference frames commonly utilised by experts studying disasters and human responses to hazards, such as 'objective historicism' (de Vries, 2011;163), and the non-linear, multidirectional 'social' or 'everyday' perceptions of time and temporality commonly experienced by people in their daily lives in the past, present and future (Fincher et al., 2014). In the context of climate change, Adam (1998) refers to this as a 'temporal disjuncture' where scientific knowledge validates the climate risks with reference to the visible present, while the impacts of alterations in global weather patterns are often latent, taking 30-40 years to accumulate invisibly and are neither spatially nor temporally consistent over time. This is exacerbated when climate change is communicated as a phenomenon that is measurable, quantifiable and predictable (Brace and Geoghegan, 2010; Doyle, 2013; Grosz, 1999) whereas 'environment time' is perceived as more rhythmic, cyclical and interconnected (Adam, 1994). As Doyle (2013;25) states, 'while clock time has enabled the identification of changes in the climate over a period of time through accumulation of meteorological data, it has simultaneously locked climate change into scientific definitions and predictions about rapidity and magnitude of future climate change'.

The future oriented nature of climate change discourse - generated through practices of 'calculation, imagination and performance' - identifies scenarios of what we are moving towards, and the mitigation and adaptation strategies that need to be adopted in order to pre-empt and prepare for them (Anderson, 2010;783). The future thus appears predictable and, therefore, can be mitigated through the adoption of a particular set of predetermined policy prescriptions within a short timeframe and with supposedly known outcomes. Such perspectives, and the policies that stem from them, can ignore the 
steps and strategies that people use to imagine and realise their own futures, or as Appadurai puts it, 'their capacity to aspire' (Appadurai, 2004). Furthermore, the possibility of devising alternative strategies or holding other non-climate change inflected aspirations is foreclosed. Doyle (2013:24) notes that 'IPCC reports and findings convey that climatic changes in the future have already been committed to in the present, but this present remains invisible, making it difficult to communicate as a reality without visual evidence'. There is a tendency, then, for the future-orientated nature of climate change discourse, 'to empty out the present'. In this paper we demonstrate the importance of understanding the past and present in order to more fully acknowledge and engage with the future strategies of non-elites and to recognise that these may be different to those laid out in the prescriptions of policy makers.

Besides this distant future orientation, environmental scientists and professionals have created a sense of impending crisis by invoking a policy discourse of immediacy and urgency. The 'climate apocalypse' imaginary (Levy and Spicer, 2013) is summarised by Swyngedouw (2010;215) as: 'The environmental conditions and, in particular, global climate change [that] are increasingly staged as signalling a great danger, of epic dimensions, that, if unheeded, might radically perturb, if not announce the premature end of civilisation before its sell-by date has passed'. Even though recent scholarship demonstrates that future representations of global climate change by analysts and commentators are not consistently negative in outlook (Fløttum et al., 2014), there is a tendency, particularly in the media, to create and reinforce 'a rising sense of an impending catastrophe for the developing world that is defenceless without the help of the West, perpetuating, to an extent, views of the poor as victims' (Doulton and Brown, 2009;191).

These representations are very much evident in present-day political debates and images that foreground the immediate threat of rising sea levels to small tropical islands (Carrington, 2013). Such 
discourses have articulated an automatic link between climate change and large scale movements whereby island communities have been projected as those in crisis (Lazrus, 2009). This sense of speed and immediacy can divert attention away from, and conceal, people's more immediate and present-day concerns that include multiple and interconnected social, economic, political and environmental vulnerabilities. Additionally, it renders invisible strategies that people have always adopted, and continue to utilise, to address changes in the climate in the context of sustaining a livelihood and building a better future for subsequent generations.

One such every day strategy is migration. This came to widespread public attention following research in the early 2000s into 'climate change refugees', and the widely circulated figure that there could be as many as one billion such refugees by 2050 (Baird et al., 2007). According to this early research, migration is primarily viewed as a problem, or social cost, and an indication of a failure to adapt. More recently, however, work carried out by the Foresight Project on Migration and Global Environmental Change (Foresight: Migration and Global Environmental Change, 2011) has shifted the terms of the debate away from refugees and towards 'drivers of migration'. Under this latter conception, migration is viewed as a more ordinary phenomenon that people undertake due to a wide range of social, economic, political and environmental reasons and, as such, represents a potential adaptation strategy in addition to all the other strategies that people might have at their disposal. According to Farbotko \& Lazrus (2011) and Mortreux and Barnett (2008), island-based communities have long histories of migration that are often overlooked by international policymakers and campaigners, and culture, lifestyle and connection to place are more significant drivers of migration than climate (Barnett and Webber, 2009). Such studies oppose the 'exodus' scenario imagined by outsiders which label them as 'climate refugees' in waiting wherein the possibility of living in their homeland is discounted, and adaptation is only possible by means of migration (McNamara and Gibson, 2009). The following 
section builds on these ideas by showing how such ideas and perceptions operate in the context of the Maldives.

\section{$3 \quad$ Case study and methods}

The Maldives provides a particularly rich case study for the exploration of elite and non-elite perceptions of climate change. The country consists of 1,192 islands covering a total of 298 square kilometres, and it has an Exclusive Economic Zone (EEZ) of nearly one million square kilometres. Its population of 380,000 people, however, inhabits only 192 islands. The country faces a number of socioeconomic challenges, with 16 percent of the population living below the poverty line, unemployment at 20 percent, and an economy heavily dependent on tourism that accounts for almost 30 percent of GNP. The national capital, Malé, is one of the most densely populated in the world, with 104,000 people living in less than six square kilometres.

In recent years, the country has attracted a great deal of international attention concerning climate change as, if the current pace of sea level rise continues, even a small increase could inundate large parts of the archipelagos (Carrington, 2013; IPCC, 2014). This raises issues of the potential for, and consequences of, large-scale migration from the country. Alarmed by these prospects, the Maldivian government has initiated several national strategies, including the reintroduction of a proposal to consolidate the population dispersed over 200 islands onto 10-15 'safer islands', albeit with potentially serious social and cultural consequences (Kothari, 2014; Riyaz and Park, 2010). While this policy has largely been viewed unfavourably by the public, it is not new (Riyaz and Park, 2010). Population consolidation is also described as an adaptation strategy in the government's 2007 National Adaptation Programme for Action (NAPA) on climate change. These policies resonate with experiences of when entire populations have been relocated from islands where livelihoods were no longer sustainable. For 
example, following the Indian Ocean tsunami in 2004, 1600 people from several island communities were resettled (Riyaz and Park, 2010).

It is in this context that the terms 'elites' and 'non-elites' are invoked in order to differentiate between different kinds of knowledge, perceptions and influence. In general, 'elites' refers to development professionals and policymakers working at national and international levels. This category includes academics, government officials, and policymakers from NGOs who hold positions of power within organisations, and who therefore influence the national scientific, political, business and media agendas (Herod, 1999). These individuals are distinguished from non-elites which mainly consist of 'ordinary' people with limited influence over policymaking but who are likely to be most immediately and directly affected by changes in the environment and are often amongst the most vulnerable and marginalised (Hart and Victor, 1993; McCright and Dunlap, 2011).

It is recognised that distinctions between these groups can be blurred, and that individuals might move between them depending on professional sector or geographical location (Fritzen, 2007). For example, an environmental policymaker might be influential in the NGO sector but wield relatively little authority within government ministries. Moreover, a powerful politician stationed in the nation's capital might have limited influence in a provincial city where his or her status is not recognised. Conversely, some leaders viewed as elites in the local context might be regarded as people with relatively low status whilst interacting with elites from central government departments. Notwithstanding these nuances, however, the elites/non-elites distinction is useful in highlighting the tendency in climate change discourse to separate largely international, scientific and professional knowledge from that of nonexpert individuals and groups. 
Fieldwork for the data presented in this paper was undertaken over three periods, July-August 2013, October 2013 and September 2014, on Malé, Guraidhoo and Dhuvaafaru islands. Guraidhoo is located in the south Male atoll, 30 minutes by speedboat and two hours by ferry from the national capital. The island has a population of approximately 1700 people and its economy is dominated by the nearby Kandooma holiday resort which employs many young people from the island. Dhuvaafaru is located in the eastern edge of the northern Raa Atoll, about $170 \mathrm{kms}$ from Malé. It has a population of approximately 5000 people and was established as a resettlement community following the Indian Ocean tsunami in 2004. Its economy is dominated by fishing due to an absence of holiday resorts in the area. Although some minor differences in perspectives of climate change between Guraidhoo and Dhuvaafaru were found in the data, the elite-non elite distinction was discovered to have a much greater effect, hence the focus on the latter theme in this article.

In these locations, semi-structured interviews were conducted to allow in-depth discussion with respondents relating to issues such as environmental and climatic change, economic development, and migration (Longhurst, 2003). In total, 35 elites and 39 non-elites were interviewed. Elites were selected for interview based on a snowballing sampling strategy designed to access information rich cases or 'key informants' (Atkinson and Flint, 2001). Most elite interviewees were Maldivian nationals, although a minor proportion was expatriate staff, and most were resident in Malé, although the views of island-based leaders was also sought. In addition, most elites had jobs that focussed on climate change or environmental protection, although a small number, such as those working in the tourism sector, were not actively preoccupied with climate change in their daily affairs. Thus, many of the quotations in the analysis that follows reflect the views of those who actively engage with climate change issues on a regular basis. Non-elites were mostly 'ordinary' people living on Guraidhoo and Dhuvaafaru islands who were engaged in livelihood activities such as small-scale fishing and low-paid jobs in the tourism sector, although a small number of individuals based in Malé were also consulted, 
mostly in an informal manner. Non-elites were selected for interviews taking into account demographics such as age, gender and social status to gather a range of opinions and insights.

Elite interviews were conducted in English and non-elite interviews were carried out in the national language, Dhivehi, with the aid of a translator. A Dictaphone was used to record interviews with elites which were then transcribed; for non-elites, handwritten notes were taken during meetings which were written up afterwards. In addition to interviews, a number of policy documents and government reports, such as the country's 2007 NAPA, were consulted to supplement the interview data being gathered. At the end of the last phase of fieldwork, a one-day workshop was held with 25 elite stakeholders to feed back the initial findings emerging from the research. This event allowed the researchers to discern what sense was being made of their data interpretations.

\section{$4 \quad$ Perceptions of climate change and migration in the Maldives}

Research in the Maldives confirms that, as Hulme (2007) writes, the idea of climate change has travelled. However, it is also being reworked in specific places and contexts to produce multiple understandings, meanings and responses. In this section, we demonstrate differences in temporal understandings by providing different perspectives of environment- and climate-induced change. We then show how these differences are reflected in the form and extent of responses to climate change, with a particular focus on migration.

\subsection{Different understandings of temporality and crisis}

While elites focus on a distant future which is generally abstracted from people's lives, non-elites tend to construct their futures through their personal experiences that are located in their understandings of the past and their knowledge of the present. For example, the problem of sea level rise dominates international discussions on climate change and small island states, with the IPCC predicting an 
approximate sea level rise of 0.5 meters by 2100 leading to risks such as loss of livelihoods, coastal settlements, infrastructure, ecosystem services, and economic stability (Nurse et al., 2014). However, many of those living on small islands tended to downplay the significance of this phenomenon, with one person commenting, 'I have heard from the news that our islands are going to disappear but I do not believe this is occurring'. This scepticism was often repeated by islanders who tended to focus much more on events that they had experienced personally. To illustrate, a district government officer stated:

"If you ask local people about fuel or food subsidy, they would be interested to talk about it, as it affects their daily life, but climate change-induced sea level rise is not a concern as it is occurring so far ahead. They do not know and don't understand what TV or newspapers have to say about this".

Of the various environmental changes experienced by local islanders, the problem of beach erosion was of much greater concern than sea level rise. Beach erosion negatively impacts on local jetties, thus having a much more direct impact on access to food and fuel that arrives daily by ferry. Many interviewees were concerned that, since their youths, their islands had shrunk significantly, that trees had been lost, and beaches reduced in extent. To illustrate, a programme officer from an international donor organisation explained, 'People see and feel the impacts of environmental change... but they can't see climate change, so they don't know why they have to think about it'. Thus, non-elites were concerned about what problems contemporary environmental changes might lead to for their children but often did not speak of a more distant future.

This personal experience combined with a focus on their immediate environments also meant that geographically remote events were not readily believed or accepted. For example, one worker for an environmental advocacy NGO stated, 'Local people cannot imagine what a glacier or iceberg is and 
that it is melting far away due to climate change and causing sea levels to rise'. This view was often encountered during interviews with islanders, some of whom were doubtful that the phenomenon of glacier mass loss due to global warming could have an appreciable effect in a country as distant as the Maldives, whereas others viewed ocean thermal expansion as implausible given the already tropical nature of the Maldivian climate. To illustrate, one fisherman argued, 'The Maldives is already a hot place and the sea has a lot of energy... [The sea] rises and it falls almost day to day, but we don't see it causing any problem to us. If there is more water then there is more fish to catch'.

This time-related disjuncture about the past/present and future is linked to a second divergence, with elites tending to focus on the narrative of a 'crisis' and non-elites not envisaging changes with the same sense of urgency. In the Maldives there has been a clear construction of a crisis narrative with the tourist sector advertising 'come to Maldives before they sink'1 and the publicity surrounding the historic underwater cabinet meeting held by President Nasheed in 2009. This discourse around 'sinking islands' due to sea level rise is familiar to local people through visual and print media. However, the vast majority did not identify with these concerns due to what they perceived to be alarmist claims with no 'evidence'. As explained above, the 'evidence' that non-elites relied upon rarely related to the claims or predictions of expert scientists but rather their personal observations and their past and present experiences of changes in their immediate surroundings. To illustrate, one fisherman stated, 'I have heard that the islands are sinking but I do not believe this. It is not something that I have noticed. The rainfall changes and the beaches too but this has always happened. It is not an emergency'. This quotation is not intended to demonstrate that islanders are climate change sceptics, or that they are short-sighted and parochial. Instead, it shows that they tend to prioritise present day livelihoods challenges, which may include changes in their physical environment, over a process that appears to

\footnotetext{
${ }^{1}$ For example, a 2013 travel article produced by the online magazine, Business Insider, stated 'Visit The Beautiful Maldives Islands Before They're Gone Forever'. http://www.businessinsider.com/the-maldives-islands-main-attractions-2013-2?op=1
} 
be developing unperceptively slowly over decades and therefore does not appear to represent a threat to them.

Islanders were able to relate to the concept of environmental crisis but these ideas were lodged in past experience, not in future scenarios. Although not related to climate change, the tsunami of 2004 was often referred to during discussions on floods, rainfall and storm surges. The event was vividly remembered with frequent recounting of how seawater entered compounds and flooded residential areas. For many islanders it was the 'big event', following which people began observing increased storm surges or 'big waves'. For example, one elderly fisherman noted changes in temperature and rainfall following the tsunami when he said, 'It is hotter now, rains are delayed, in my younger days rains came by May, now they are slow in coming' and described how these changes had impacted on his daily life, 'Older people could predict high seas to avoid fishing, now our calculations have failed as things have changed'. In addition, while numerous islanders stated that they had experienced sea level rise following the tsunami, many did not associate it with wider-scale global processes, believing instead that it was only their own particular island that was being affected.

In spite of the ferocity of the tsunami, and even though some people were resettled as a result, many non-elites felt that they were, and always have been, resilient. As one interviewee commented, "We have always managed...nothing so bad has happened to us. We will always survive by building sea walls, floating islands, underwater homes, whatever we need to do'. This sense of optimism about the future, coupled with a feeling of general capability in the face of adversity, meant that very few nonelites identified with the notion of a future climate change-related crisis, even when presented with the basic facts of climate science. For example, one interviewee, a small business owner based in Malé, stated: 'I don't believe there is any crisis coming [due to climate change]. We survived the tsunami and we will also survive anything else that comes our way'. In this case, the individual was using her 
understanding and experience of past events to emphasise the resilience of the Maldivian people to future potential impacts.

\subsection{Responses to climate change: past, present and future}

As a result of these divergences in perceptions, understandings and priorities between elites and nonelites, the interventions of policymakers to build climate change awareness and action in the Maldives has often ended in frustration. For example, many school-leavers in the Maldives are aware of longterm climate change due to the integration of the topic into the national curriculum, as well as a national UNICEF-sponsored climate change awareness programme. However, the government and NGObased personnel involved in these initiatives explained how these interventions had mixed results. Ordinary islanders, they stated, often did not seem interested in listening to them, nor did they appear to take on board their messages concerning the need to act now to combat climate change. As a result, many elites described how interventions that were meant to help people adapt to the impacts of climate change, such as rainwater harvesting, kitchen gardens and tree planting, had to be presented to island-based communities as development initiatives, and not as a response to climate change.

It was common for elites to attribute this apparent lack of interest in climate change to fatalism deriving from local religious beliefs. Indeed, during interviews islanders often said that long term climatic change was an act of God and that if a disaster occurred then God would take care of them. Others stated that humans had nothing to do with climate change and that the phenomenon was the result of a 'superior power'. Islanders commonly invoked religious ideas to explain why climate change is occurring, with one elderly fisherman suggesting that, 'If people go against religion then nature will come back to punish them'. These views were generally seen by elites as barriers to the implementation of adaptation strategies with one environment official asking, 'How can we raise awareness of climate change and its impact if people believe it is God-given and there is nothing they can do?' 
The prevalence of these views suggests that a fatalistic or apathetic attitude towards climate change was indeed prevalent amongst non-elites. However, it also became clear in interviews that non-elites preferred to focus on issues over which they had some degree of personal control in the present day, such as investing in their families' education to give their children and grandchildren a better future, rather than worry about something long-term such as climate change. For example, a programme officer of an international donor organisation explained that, 'People will not listen if you bring in the climate change angle. They just wouldn't pay any attention to you. But if you bring in issues that have some impact on them now, such as opportunities for their kids, then that's the kind of issue that they will really take notice of'. Thus, in this sense, reference to God or a 'superior power' was simply a way of indicating that long term climate change was something over which islanders felt they had relatively little control. This finding correlates with the argument advanced above that the sense of speed and immediacy associated with action to respond to climate change can divert attention away from more immediate concerns that people might have.

As a result of the perceived crisis of climate change, as well as the apparent apathy and fatalism amongst local people, many elites in the Maldives viewed displacement and involuntary resettlement of people as an inevitable outcome of climate change, which would be socially, economically and culturally traumatic for people. One policymaker working for a national-level environmental campaign group summed up the prevailing viewpoint:

'People don't see what is coming. In 20 years many of these [islands] will not be habitable due to saltwater inundation. In 50 years they might not even exist. It is like a ticking time-bomb sitting right under people's noses...People will be forced to move away from their islands, which will be bad for 
them, but they just can't see it... This is why it is so important for all Maldivians to join forces and act now'.

In this quotation, the interviewee is using the future possibility of catastrophic, mass population displacement to justify present day action. However, this dominant narrative on the inevitability of damaging climate change-induced migration contrasted with perspectives and beliefs emerging from discussions with non-elites in two main ways. First, similar to the case of Tuvalu reported by Mortreux and Barnett (2008) and Shen and Gemenne (2011), many Maldivian non-elites did not see sea-level rise as a sufficient reason to migrate should it occur in the near- to medium-term future as they believe they have other ways and means to adapt. To illustrate, one fisherman described how the island where he lived was well-defended from the sea, and if sea levels really did rise then it would be possible to develop sea-defences to keep the waters back. Similarly, other non-elites stated that concerns expressed about saltwater intrusion were overstated as many island communities were already successfully using new technologies to turn seawater into drinking water. Thus, while ideas about population mobility form a significant part of the 'crisis' narrative used by elites when discussing migration in the context of climate change, many islanders did not see moving as the first and only possible adaptation strategy. Indeed, their repertoire of adaptation strategies, which form a part of islanders' 'capacity to aspire' (Appadurai, 2004; see section 2), appeared to be more extensive and integrated into their everyday lives than those suggested by climate change professionals.

Second, if involuntary migration was indeed an outcome of long term climate change in the Maldives, then the positive and negative impacts of this were far from certain. In general, migration of populations away from SIDS islands threatened by long-term climate change and sea level rise is seen as potentially socially, economically and culturally disruptive, not least due to the significance of placeidentity and place-attachment (Adger et al., 2011; Baxter and Armitage, 2012; Graham et al., 2013; 
Novaczek et al., 2011). Elites commonly referred to the strong notions of home, place and identity that non-elites possessed. . Indeed, this was evident in interviews with non-elites where a sense of place and familiarity with the culture and language of their place of birth or specific land were central to their identity and feelings of belonging. For example, a woman noted, "People here live in particular tradition and belief systems and I believe that these will save us. I want to live and die here". Another commented that 'people who are born and brought up here don't like it anywhere else. I moved for seven months but quit my job in the mainland and came back here'.

The prevalence of these sentiments and attachments suggest that any form of future involuntary migration in the Maldives might indeed have negative repercussions for those compelled to relocate. However, it became clear during interviews with non-elites that many Maldivians have for decades migrated between islands, particularly to and from Malé, in search of better employment, education and healthcare opportunities for themselves and their families. . This is similar to the situation reported by Farbotko and Lazrus (2011) in Tuvalu where residents of these islands have long histories of migration that have been overlooked by global climate change narratives. In the Maldives, however, a generation gap between older and younger people was discernible in relation to perceptions of any climate change-induced migration that might eventually occur. In general, older interviewees preferred to stay where they were, but were also relatively open to the prospect of relocating provided that the national government covered the costs of resettlement in full. In contrast, many younger interviewees viewed climate change induced migration as a potential opportunity to secure a better life elsewhere. For example, one 25 year old interviewee, 'Yauqoob', who was travelling back and forth between Malaysia for catering college stated:

"I have heard of climate change from the television but I am not so worried...If sea-level rise occurs then I will go to Dubai because there is work there and good socioeconomic conditions. Then I'll be 
able to provide support to my parents and family. Here [in Dhuvafaaru] there is not so much for me as there are no jobs".

Yauqoob's case, in addition to the other examples reported in this section, provides an illustration of how the sense of urgency created by the climate change discourse coalition in the Maldives has effectively invisiblised his ability to visualise an improved future for himself and his family in the future in spite of the warnings of danger and imminent threat.

As shown above, there is a diverse range of forms of knowledge and responses to issues around climate change and migration. These are variously interpreted with the apparent short-sightedness of non-elites often set against the temporally extensive view of experts, with science privileged over experience, and with global knowledge given precedence to local observations. What we suggest here is that these differences are, in part, based on divergences in understandings of time-scale and temporality in the ways in which people understand the past, present and future, and the associated notions of crisis and urgency. These differences have thus far been largely underestimated in analyses of perceptions of climate change despite their significance in shaping how observable changes are explained and interpreted, and the kinds of responses proposed and implemented.

\section{$5 \quad$ Conclusions}

Climate change presents an important global challenge, including its potential influence on human migration and mobility. However, there are multiple, and sometimes conflicting, political interests and agendas shaping how narratives of climate change and migration are produced, circulated and interpreted (Bettini, 2013; Hartmann, 2010; Nicholson, 2013). Thus, climate change and migration discourse is understood and acted upon in various ways by different groups. Two key groups explored in this article are elites and non-elites, which although not homogenous or clearly bounded, do project 
identifiable differences in climate change knowledge, understandings and responses. Taking the example of the Maldives - often referred to as in the forefront of climate change impacts in the developing world - this article has identified and explored two specific differences. The first is between the long- and short term. This arises, we argue, not only because of differences in knowledge, priorities, and agendas, but also due to varied understandings of the timescales involved in climate change. The second difference is between the crisis narratives, often invoked by elites on the international stage, and the more 'everyday' and routine perceptions of non-elites. Here, impacts of changes and alterations are already being incorporated into people's day-to-day lives and are therefore inseparable from their lived realities which also include routine issues around education, livelihoods and health.

Whilst it is important to recognise the existence of variations between elite and non-elite perspectives, it should be borne in mind that different discourses might be appropriate for different political and social arenas. In the case of the Maldives, for example, the 'urgency' discourse clearly plays a significant role in highlighting the problems that Small Island Developing States face on the international climate change stage. However, as this research shows, problems can begin to arise when these global, external facing narratives are unproblematically mapped wholesale onto ordinary peoples' lives and experiences, and when the perceptions of non-elites are not fully acknowledged in the understandings and prescriptions of global policymakers. These processes can result in an assumed one-way, unilinear transfer of knowledge from 'professionals' to 'islanders', whereby the latter are imagined as having little understanding of changes in the climate and as lacking interest in responding to emerging challenges. Instead, as we have shown, non-elites are very much aware of changes and do respond but in ways that are often invisible to elites and, therefore, go largely unrecognised because they tend to be incorporated into their everyday strategies.

In highlighting these issues, it is not the intention of this article to suggest that the long term/short term and crisis/everyday are strict dichotomies that necessarily sit in direct opposition to one-another. For 
example, non-elites, as well as being concerned with the day-to-day and the mundane, are clearly capable of envisaging a longer-term future for themselves and their families, and of taking a wider perspective as they develop their livelihood strategies that might include, but do not necessarily rely on, migration. Neither is it the intention to generalize the insights provided in this article to all contexts where climate change and migration intersect. For example, recent work on in Alaska conducted by Marino and Schweitzer (2009) has shown that local discourses on climate change are more urgent than their bureaucratic counterparts. This reflects the IPCC's argument that the heterogeneity and complexity of small island states and territories should be acknowledged and that there is a need to transfer data from one small island state to another with care and caution (Nurse et al., 2014).

What we suggest here is that there needs to be improved dialogue between elites and non-elites on issues such as climate change and migration, and that different perspectives need to be integrated more effectively. In the Maldives, there are signs that awareness of the need for this type of discussion is emerging. For example, in the feedback workshop run by the authors of this article in 2014 (see Section 3), one influential policymaker from an international donor organisation commented that, out of all the hundreds of workshops on climate change that have occurred in the Maldives since evidence of the problem first emerged from the scientific community in the 1980s, there has never been an event that has tried to take into account non-elite, local understandings and perspectives on the problem. It is our hope that this paper can go some way to addressing this shortcoming.

\section{References}

Adam, B., (1994) Running out of time: global crisis and human engagement, in: Redclift, M., Benton, T. (Eds.), Social Theory and the Global Environment. Routledge, London.

Adam, B. (1998) Timesacpes of Modernity: The Environment and Invisible Hazards. Routledge. , London.

Adger , W.N., Barnett, J., Chapin III, F.S., H, E. (2011) This must be the place: underrepresentation of identity and meaning in climate change decision-making. Global Environmental Politics 11, 1-25.

Anderson, B. (2010) Preemption, precaution and preparedness: anticipatory action and future geographies. Progress in Human Geography 34, 777-798. 
Appadurai, A., (2004) The Capacity to Aspire: Culture and the Terms of Recognition in: Rao, V., Walton, M. (Eds.), Culture and Public Action. World Bank, Washington D.C.

Arnall, A.H. (2014) A climate of control: flooding, displacement and planned resettlement in the Lower Zambezi River valley, Mozambique. Geographical Journal 180, 141-150.

Arnall, A.H., Kothari, U., Kelman, I. (2014) Introduction to politics of climate change: discourses of policy and practice in developing countries. The Geographical Journal 180, 98-101.

Artur, L., Hilhorst, D. (2011) Everyday realities of climate change adaptation in Mozambique. Global Environmental Change 22, 529-536.

Atkinson, R., Flint, J., (2001) Accessing hidden and hard-to-reach populations: snowball research strategies, Social Research Update

Baird, R., Migiro, K., Nutt, D., Kwatra, A., Wilson, S., Melby, J., Pendleton, A., Rodgers, M., Davison, J., (2007) Human Tide: the Real Migration Crisis. Christian Aid London.

Ballu, V., Bouin, M.N., Siméoni, P., Crawford, W.C., Calmant, S., Boré, J.M., Kanas, T., Pelletier, B. (2012) Comparing the role of absolute sea-level rise and vertical tectonic motions in coastal flooding, Torres Islands (Vanuatu) Proceedings of the National Academy of Sciences 108, 1301913022.

Barnett, J., Webber, M., (2009) Accommodating migration to promote adaptation to climate change. Commission on Climate Change and Development, Stockholm.

Baxter, J.A., Armitage, D. (2012) Place identity and climate change adaptation: a synthesis and framework for understanding. WIREs Climate Change 3, 251-266.

Bettini, G. (2013) 'Climate Barbarians at the Gate? A critique of apocalyptic narratives on 'climate refugees'. Geoforum 45, 63-72.

Brace, C., Geoghegan, H. (2010) Human geographies of climate: landscape, temporality and lay knowledges. Progress in Human Geography 35, 284-302.

Carrington, D., (2013) The Maldives is the extreme test case for climate change action, The Guardian, London.

CDKN, (2014) The IPCC's 5th Asssessment Report: What's in it for Small Island Developing States? Climate and Development Knowledge Network, London.

de Vries, D.H. (2011) Temporal vulnerabilty in hazardscapes: flood memory-networks and referentiality along the North Carolina Neuse River (USA). Global Environmental Change 21, 154-164.

Doulton, H., Brown, K. (2009) Ten years to prevent catasrophe? Discourses of climate change and international development in the UK press. Global Environmental Change 19, 191-202.

Doyle, J. (2013) Mediating Climate Change. Ashagte Publishing Limited, Surrey, England.

El-Hinnawi, E. (1985) Environmental Refugees. United Nations Environment Programme, Nairobi.

Farbotko, C., Lazrus, H. (2011) The first climate refugees? Contesting global narratives of climate change in Tuvalu. Global Environmental Change 22, 382-390.

Featherstone, D. (2013) The contested politics of climate change and the crisis of neo-liberalisation. ACME: An International E-Journal for Critical Geographies 12, 44-64.

Felli, R., Castree, N. (2012) Commentary: Neoliberalising adaptation to environmental change: foresight or foreclosure? Environment and PLanning A 44, 1-4.

Few, R., Brown, K., Tompkins, E.L. (2007) Public participation and climate change adaptation: Avoiding the illusion of inclusion Climate policy 7, 46-59.

Fincher, R., Barnett, J., Graham, S., Hurlimann, A. (2014) Time stories: making sense of futures in anticipation of sea-level rise. Geoforum 56, 201-210.

Fischer, F., Hajer, M.A., (1999) Living with Nature: Environmental Politics as Cultural Discourse Oxford University Press, Oxford.

Fløttum, K., Gjesdal, A.M., Gjerstad, Ø., Koteyko, N. (2014) Representations of the future in English language blogs on climate change. Global Environmental Change 29, 213-222.

Foresight: Migration and Global Environmental Change, (2011) Final Project Report: Executive Summary. The Government Office for Science, London. 
Fritzen, S.A. (2007) Can the design of community-driven development reduce the risk of elite capture? Evidence from Indonesia. World Development 35, 1359-1375.

Gaillard, J.C. (2010) Vulnerability, capacity and resilience: perspectives for climate and development policy. Journal of International Development 22, 218-232.

Gerrard, M.B., Wannier, G.E., (2013) Threatened Island Nations: Legal Implications of Rising Seas and a Changing Climate. Cambridge University Press, Cambridge.

Graham, S., Barnett, J., Fincher, R., Hurlimann, A., Mortreux, C., Waters, E. (2013) The social values at risk from sea-level rise. Environmental Impact Assessment Review 41, 45-52.

Grosz, E., (1999) Thinking the new: Of futures yet unthought, in: Grosz, E. (Ed.), Becoming: Explorations in Time, Memory and Future. Ithaca, NY, pp. 15-28.

Hajer, M., Versteeg, W. (2005) A decade of discourse analysis of environmental politics. Journal of Environmental Policy \& Planning 7, 175-184.

Hart, D.M., Victor, D.G. (1993) Scientific elites and the making of US policy for climate change research, 1957-74. Social Studies Science 23, 643-680.

Hartmann, B. (2010) Rethinking climate refugees and climate conflict: rhetoric, reality and the politics of policy discourse. Journal of International Development, 233-246.

Herod, A. (1999) Reflections on interviewing foreign elites: praxis, positionality, validity, and the cult of the insider. Geoforum 30, 313-327.

Hulme, M. (2007) Geographical work at the boundaries of climate change. Transactions of the Institute of British Geographers 33, 5-11.

IPCC, (2014) Summary for policymakers, in: Field, C.B., Barros, V.R., Dokken, D.J., Mach, K.J., Mastrandrea, M.D., Bilir, T.E., Chatterjee, M., Ebi, K.L., Estrada, Y.O., Genova, R.C., Girma, B., Kissel, E.S., Levy, A.N., MacCracken, S., Mastrandrea, P.R., White, L.L. (Eds.), Climate Change 2014: Impacts, Adaptation, and Vulnerability. Part A: Global and Sectoral Aspects. Contribution of Working Group II to the Fifth Assessment Report of the Intergovernmental Panel on Climate Change. Cambridge University Press, Cambridge, United Kingdom and New York, NY, USA.

Kelman, I. (2010) Hearing local voices from Small Island Developing States for climate change. Local Environment 15.

Kothari, U. (2014) Climate change and migration: a political discourse of resettlement in the Maldives. The Geographical Journal 180, 130-140.

Lazrus, H., (2009) Sea Change: Anthropology and Climate Change in Tuvalu, South Pacific, in: Crate, S.A., Nuttall, M. (Eds.), Anthropology and Climate Change: From Encounters to Actions. Left Coast Press Inc., Walnut Creek, California.

Levy, D.L., Spicer, A. (2013) Contested imaginaries and the cultural political economy of climate change. Organization 20, 659-678.

Liverman, D. (2009) Conventions of climate change: constructions of danger and the dispossession of the atmosphere. Journal of Historical Geography 35, 279-296.

Lohmann, L. (2011) Review Essay: Capital and climate change. Development and Change 42, 649668.

Longhurst, R., (2003) Semi-structured interviews and focus groups, in: Clifford, N., Valentine, G. (Eds.), Key methods in geography. Sage, London.

Marino, E., Ribot, J. (2012) Special Issue Introduction: Adding insult to injury: Climate change and the inequities of climate intervention. Global Environmental Change 22, 323-328.

Marino, E., Schweitzer, P., (2009) Talking and Not Talking about Climate Change in Northwestern Alaska, in: Crate, S.A., Nuttall, M. (Eds.), Anthropology and Climate Change: From Encounters to Actions. Left Coast Press, Inc, California.

McCright, A., M, Dunlap, R.E. (2011) Cool dudes: The denial of climate change among conservative white males in the United States. Global Environmental Change 21, 1163-1172.

McNamara, K.E., Gibson, C. (2009) 'We do not want to leave our land': Pacific ambassadors at the United Nations resist the category of 'climate refugees'. Geoforum 40, 475-483. 
Mercer (2010) Disaster risk reduction or climate change adaptation: are we reinventing the wheel? Journal of International Development 22, 247-264.

Mortreux, C., Barnett, J. (2008) Climate change, migration and adaptation in Funafuti, Tuvalu. Global Environmental Change 19, 105-112.

Nicholson, C.T.M. (2013) Climate change and the politics of causality: the case of climate change and migration. Geographical Journal 180, 151-160.

Nielsen, J.O., Reenberg, A. (2010) Temporality and the problem with singling out climate as a current driver of change in a small West African village Journal of Arid Environments 74, 464-474.

Novaczek, I., MacFadyen, J., Bardati, D., MacEachern, K. (2011) Social and cultural values mapping as a decision-support tool for climate change adaptation. The Institute of Island Studies, University of Prince Edward Island, Charlottetown, Canada.

Nurse, L.A., McLean, R.F., Agard, J., Briguglio, L.P., Duvat-Magnan, V., Pelesikoti, N., Tompkins, E., Webb, A., (2014) Small islands, Climate Change 2014: Impacts, Adaptation, and Vulnerability. Part B: Regional Aspects. Contribution of Working Group II to the Fifth Assessment Report of the Intergovernmental Panel on Climate Change [Barros, V.R., C.B. Field, D.J. Dokken, M.D. Mastrandrea, K.J. Mach, T.E. Bilir, M. Chatterjee, K.L. Ebi, Y.O. Estrada, R.C. Genova, B. Girma, E.S. Kissel, A.N. Levy, S. MacCracken, P.R. Mastrandrea, and L.L. White (eds.)]. . Cambridge University Press, Cambridge, United Kingdom and New York, NY, USA.

Paton, K., Fairbairn-Dunlop, P. (2010) Listening to local voices: Tuvaluans respond to climate change. Local Environment 15, 687-698.

Patt, A., Schroter, D. (2008) Perceptions of climate risk in Mozambique: Implications for the success of adaptation strategies. Global Environmental Change 18, 458-467.

Rankey, E.C. (2011) Nature and stability of atoll island shorelines: Gilbert Island chain, Kiribati, equatorial Pacific. Sedimentology 58 1831-1859.

Riyaz, M., Park, K.-H. (2010) "Safer island concept" developed after the 2004 Indian Ocean Tsunami: a case study of Maldives. Journal of Earthquake and Tsunami 4, 135.

Rudiak-Gould, P. (2012) Promiscuous corroboration and climate change translation: a case study from the Marshall Islands. Global Environmental Change 22, 46-54.

Rudiak-Gould, P. (2014) Climate change and accusation: global warming and local blame in a small island state. Current Anthropology 55, 365-386.

Shen, S., Gemenne, F. (2011) Contrasted views on environmental change and migration: the case of Tuvaluan migration to New Zealand. International Migration 49(Suppl. s1), e224-e242.

Skoglund, A., Jensen, T. (2013) The Professionalization of Ethics in the Intergovernmental Panel on Climate Change (IPCC): From Servant of Science to Ethical Master? . Sustainable Development 21, 122-130.

Stojanov, R., Kelman, I., Martin, M., Vikhrov, D., Kniveton, D., Duží, B., (2014) Migration as Adaptation? Population Dynamics in an Age of Climate Variability. Global Change Research Centre, The Academy of Sciences of the Czech Republic, Brno.

Swyngedouw, E. (2010) 2010. Apocalypse Forever? Post-political populism and the spectre of climate change 27, 213-232.

Tacoli, C., (2009) Crisis or adaptation? Migration and climate change in a context of high mobility, in: Guzmán, J.M., Martine, G., McGranahan, G., Schensul, D., Tacoli, C. (Eds.), Population Dynamics and Climate Change. UNFPA and IIED, New York and London.

Tanner, T., Allouche, J. (2011) Towards a new political economy of climate change and development. IDS Bulletin 42, 1-15.

Webb, A.P., P.S, K. (2010) The dynamic response of reef islands to sea-level rise: evidence from multi-decadal analysis of island change in the Central Pacific Global and Planetary Change 72 234-246.

Yamamoto, L., Esteban, M. (2014) Atoll Island States and International Law: Climate Change Displacement and Sovereignty. Springer, Berlin. 